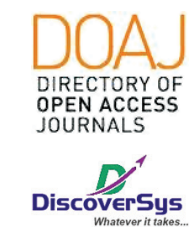

Published by DiscoverSys

\section{Sistem tunggal ureter ektopik dengan ginjal multikistik displastik di RSUP Sanglah, Bali, Indonesia: laporan kasus}

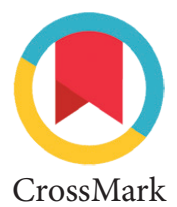

\author{
Donny Oktavius, ${ }^{1 *}$ Gede Wirya Kusuma Duarsa²
}

\begin{abstract}
Background: Ectopic ureter is a condition when the ureter does not enter the bladder properly. The occurrence of the ectopic ureter is 1:2.000 - 1:4.000 in general population with gender ratio $6: 1$ in favour of females. More than $80 \%$ of cases of ectopic ureters are generally associated with complete duplication of the pelvic-ureteric system. Still, the ectopic ureter can also occur in a single pelvic-ureteric system, which is typically dysplastic or poorly functioning, such as in multicystic dysplastic kidney. This study aims to evaluate the current management of a single ectopic ureteral system with dysplastic multicystic kidneys at Sanglah General Hospital, Bali, Indonesia.

Case Description: A 3-year-old girl was referred to the urology clinic of Sanglah General Hospital with chief complaint cloudy urinary since
\end{abstract}

1,5 years ago. Past medical history, the patient had a recurrent urinary tract infection with fever. Physical examination and laboratory findings were normal. However, an abdominal ultrasound showed a multicystic dysplastic kidney. VCUG showed vesicoureteral reflux grade $V$ and ectopic ureter. Cystoscopy with retrograde pyelography and ureterorenoscopy showed an ectopic ureter opening was located in the proximal urethra above the external sphincter. Nephroureterectomy was performed. After the surgical procedure, the patient was treated and had no complaint. The patient was discharged from the hospital four days after surgery. Conclusion: The management of ectopic ureteral cases varies for each case. In this regard, the nephroureterectomy surgery performed in the case has provided good outcomes.

Keywords: Ectopic Ureter, Multicystic Dysplastic Kidney, Single Pelvic System

Cite This Article: Oktavius, D., Duarsa, G.W.K. 2020. Sistem tunggal ureter ektopik dengan ginjal multikistik displastik di RSUP Sanglah, Bali, Indonesia: laporan kasus. Intisari Sains Medis 11(1): 228-232. D0I: 10.15562/ism.v1111.551

\title{
ABSTRAK
}

Latar Belakang: Ureter ektopik merupakan suatu kondisi dimana ureter tidak masuk ke buli-buli pada tempat yang seharusnya. Insiden ureter ektopik 1:2.000 - 1:4.000 kelahiran pada populasi secara umum dengan perbandingan jenis kelamin perempuan lebih banyak daripada laki-laki, yaitu 6:1. Lebih dari 80\% kasus ureter ektopik umumnya berhubungan dengan duplikasi sistem pelvis-ureter yang lengkap. Tetapi ureter ektopik juga dapat terjadi pada sistem pelvisureter tunggal, yang pada umumnya displastik atau fungsinya buruk, seperti pada keadaan ginjal multikistik displastik. Studi ini bertujuan untuk mengevaluasi manajemen terkini pada sistem tunggal ureter ektopik dengan ginjal multikistik displastik di RSUP Sanglah, Bali, Indonesia.

Deskripsi Kasus: Seorang anak perempuan berusia 3 tahun dirujuk ke poliklinik urologi Rumah Sakit Sanglah dengan keluhan buang air kecil keruh sejak 1,5 tahun lalu. Riwayat penyakit dahulu, penderita mengalami infeksi saluran kemih berulang disertai demam. Hasil pemeriksaan fisik dan laboratorium normal. Hasil USG abdomen menunjukkan gambaran ginjal multikistik displastik, VCUG menunjukkan vesikoureteral refluks grade $\mathrm{V}$ dan ureter ektopik. Sistoskopi dengan retrograde pyelografi dan ureterorenoskopi menunjukkan muara ureter ektopik terletak di uretra proksimal di atas sfingter uretra eksterna. Lalu dilakukan tindakan nefroureterektomi. Setelah dioperasi, selama perawatan, pasien tidak memiliki keluhan. Pasien dipulangkan setelah empat hari perawatan.

Kesimpulan: Tatalaksana pada kasus ureter ektopik bervariasi untuk setiap kasus. Berkaitan dengan hal tersebut maka tindakan pembedahan nefrouretektomi yang dilakukan pada kasus tersebut telah memberikan luaran yang baik.
${ }^{2}$ Spesialis Urologi, Divisi Urologi Rumah Sakit Umum Sanglah, Fakultas Kedokteran Universitas Udayana, Denpasar, Bali, Indonesia

*Korespondensi: Donny Oktavius; Dokter umum, Fakultas Kedokteran Universitas Kristen Krida Wacana, Jakarta, Indonesia;

donnyokt@gmail.com

Diterima: 25-06-2019

Disetujui: $19-03-2020$

Diterbitkan: 26-03-2020

Kata kunci: Ureter Ektopik, Ginjal Multikistik Displastik, Sistem Pelvis Tunggal

Cite Pasal Ini: Oktavius, D., Duarsa, G.W.K. 2020. Sistem tunggal ureter ektopik dengan ginjal multikistik displastik di RSUP Sanglah, Bali, Indonesia: laporan kasus. Intisari Sains Medis 11(1): 228-232. D0I: 10.15562/ism.v11i1.551

\section{PENDAHULUAN}

Ureter ektopik merupakan suatu kondisi dimana ureter tidak masuk ke buli-buli pada tempat yang seharusnya. ${ }^{1}$ Pada laki-laki, ureter ektopik paling sering bermuara di uretra posterior, diikuti pada vesikula seminalis, vas deferens, leher buli-buli, prostat, saluran ejakulasi dan epididimis. ${ }^{1}$ Gejala 
yang sering dikeluhkan umumnya berupa infeksi saluran kemih bukan inkontinensia urin. Pada wanita, ureter ektopik dapat muncul mulai leher buli-buli sampai ke perineum, vagina, uterus dan bahkan dubur. ${ }^{2}$ Gejala klinis yang menonjol umumnya adalah inkontinensia urin., ${ }^{1,2}$

Insiden ureter ektopik 1:2.000 sampai 1:4.000 kelahiran pada populasi secara umum dengan perbandingan jenis kelamin perempuan lebih banyak daripada laki-laki, yaitu $6: 1 .^{3}$ Lebih dari $80 \%$ kasus ureter ektopik umumnya berhubungan dengan duplikasi sistem pelvis-ureter yang lengkap. ${ }^{3}$ Tetapi ureter ektopik juga dapat terjadi pada sistem pelvis-ureter tunggal, yang pada umumnya displastik atau fungsinya buruk, seperti pada keadaan ginjal multikistik displastik atau sering dikenal multicystic dysplastic kidney (MCDK). ${ }^{4}$ Hubungan antara ureter ektopik dengan displasia ginjal mungkin terkait dengan anomali yang terjadi pasa saat embriogenesis traktus urinarius. ${ }^{4}$ Terdapat beberapa metode pemeriksaan penunjang yang dapat digunakan untuk membantu menegakkan diagnosis dan mengevaluasi ureter ektopik, yaitu ultrasonografi, voiding cysto-uretrography (VCUG), intravena pielografi (IVP), MRI, CT scan dan sistoskopi. ${ }^{5}$

Ureter ektopik dengan sistem pelvis-ureter tunggal ataupun dupleks dapat menyebabkan hidronefrosis berat. Ketika fungsi ginjal masih baik atau pada keadaan duplikasi sistem pelvis ureter dengan pool atas masih berfungsi dengan baik, teknik pembedahan yang dapat dipilih berupa reimplantasi ureter atau proksimal uretero-ureterostomi. Pilihan teknik pembedahan lain adalah nefro-ureterektomi/heminefro-ureterektomi bila fungsi ginjal sudah buruk. ${ }^{6,7}$

Berkaitan dengan pemaparan di atas, maka laporan kasus ini bertujuan untuk mengevaluasi kasus sistem tunggal ureter ektopik dengan ginjal multikistik displastik di RSUP Sanglah, Bali, Indonesia maupun tata laksana terkini luaran klinis pasca tindakan operasi yang telah dilakukan.

\section{LAPORAN KASUS}

Seorang erempuan berusia 3 tahun dirujuk oleh dokter spesialis anak ke poliklinik urologi di Rumah Sakit Umum Sanglah pada tanggal 2 Februari 2019 dengan keluhan utama buang air kecil keruh sejak 1,5 tahun yang lalu. Demam, nyeri saat berkemih, kencing darah, inkontinensia dan alergi disangkal. Riwayat penyakit dahulu, penderita sering mengalami infeksi saluran kemih berulang disertai demam. Saat penderita mengonsumsi antbiotik keluhan berkurang, tetapi ketika obat habis keluhan

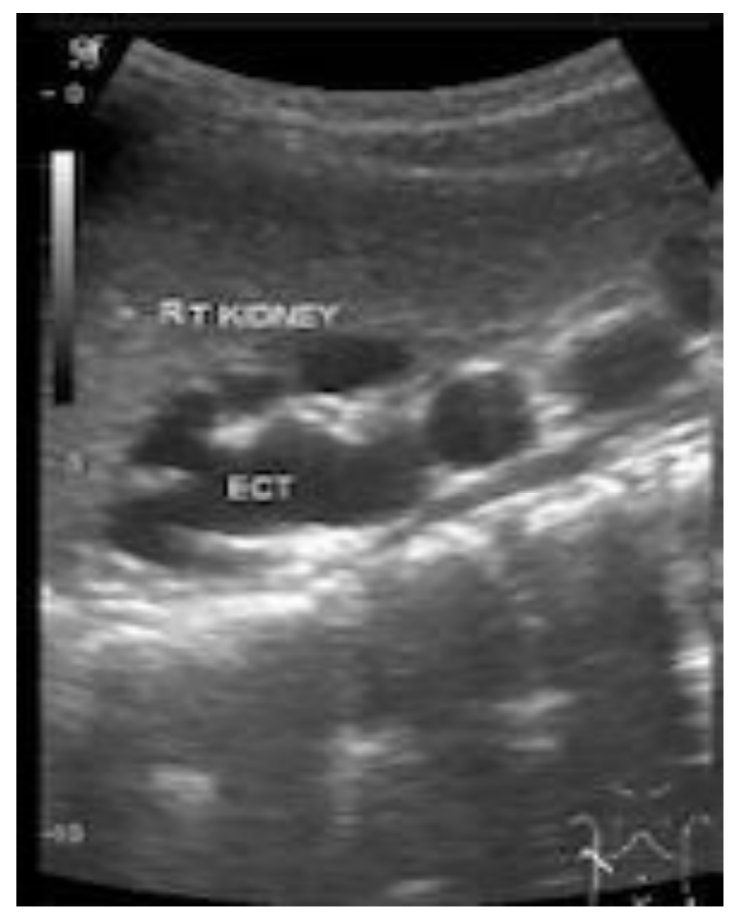

Gambar 1 Gambaran kista multipel dengan penipisan korteks ginjal

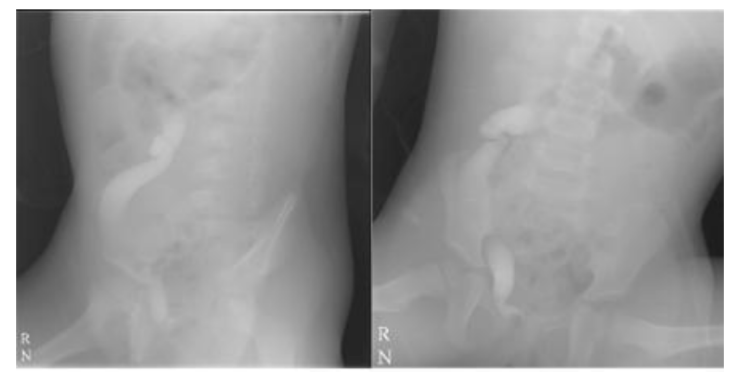

Gambar 2 Tampak pelebaran ureter dextra tourtus dan pelebaran sistem pelviokalises dextra dengan kaliks yang mendapat ballooning

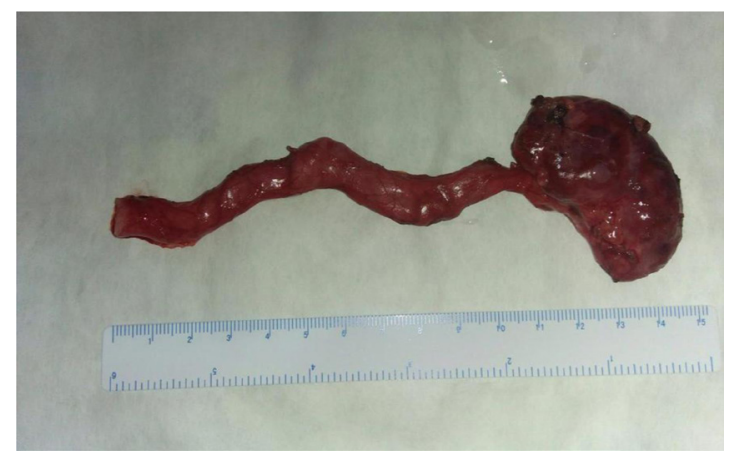

Gambar 3 Gambaran ginjal dan ureter setelah dilakukan nefroureterektomi. Ginjal berukuran $5 \times 2 \times 2 \mathrm{~cm}$ dan ureter dengan panjang $10,5 \mathrm{~cm}$ dan diameter 0,9 $\mathrm{cm}$ 


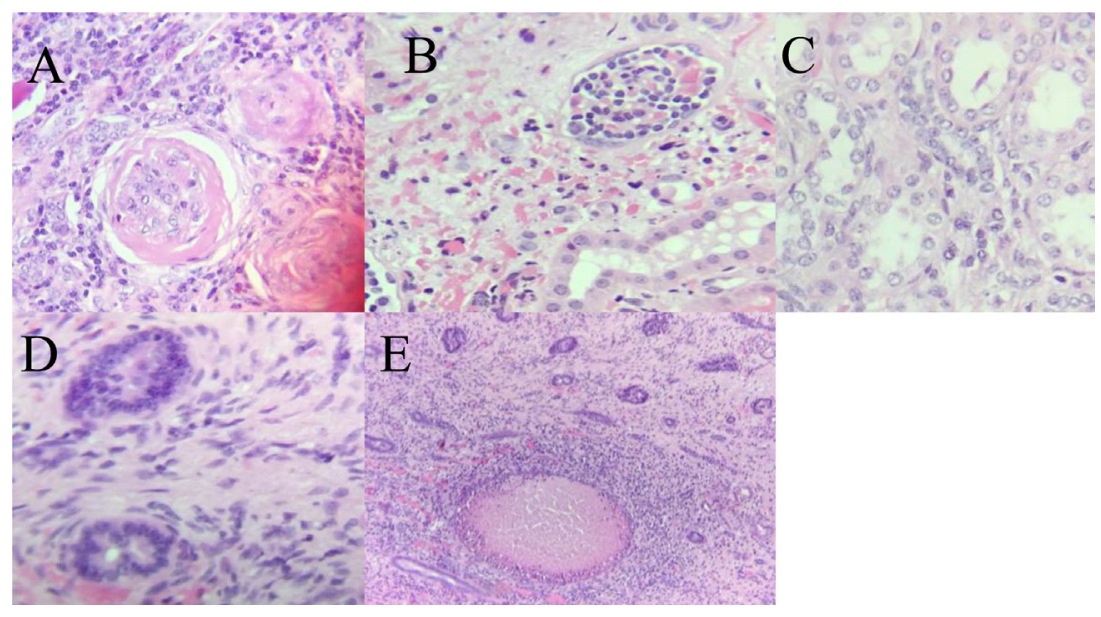

Gambar 4 Hasil histopatologi dengan pewarnaan HE (a) Sel glomeruli normal (b) Sel glomeruli sebagian tampak abortif dengan sel-sel imatur, sebagian dengan periglomerular fibrosis dan sebagian lainnya sklerotik (c) Sel epitel tubulus ginjal normal (d) Sel tubuli sebagian atrofi dengan koloidisasi, sebagian dengan vakuolisasi plasma. Pada beberapa medula sel-sel epitel tubuli tampak imatur, area peritubuli diliputi sel-sel spindel membentuk peritubular cuffing, dan stroma intertubular lebih hiperseluler (e) Mikrositik dengan lumen mengandung bahan amorf

muncul kembali. Dari hasil pemeriksaan fisik, kesadaran kompos mentis, berat badan $12 \mathrm{~kg}$, tinggi $99 \mathrm{~cm}$, suhu $36,8^{\circ} \mathrm{C}$, pernafasan $22 \mathrm{kali} /$ menit, frekuensi nadi $112 \mathrm{kali} /$ menit. Pemeriksaan fisik dari kaki sampai kepala normal. Hasil pemeriksaan laboratorium juga normal. Pemeriksaan ultrasonografi menunjukkan kistik multiple dengan penipisan pada korteks ginjal yang menggambarkan ginjal multikistik displastik (Gambar 1).

Selanjutnya dilakukan pemeriksaan voiding cysto-uretrography (VCUG) dan didapatkan vesikoureteral refluks derajat $\mathrm{V}$ dan ureter ektopik (Gambar 2). Untuk mengidentifikasi letak muara dari ureter ektopik, dilakukan pemeriksaan sistoskopi dengan retrograde pyelografi dan uretero-renoskopi. Muara ureter ektopik terletak di uretra proksimal di atas sfingter uretra eksterna. Setelah itu diputuskan untuk dilakukan nefro-ureterektomi.

Prosedur pembedahan dikerjakan dengan anestesi umum. Penderita diarahkan pada posisi lumbotomi lalu dilakukan insisi dorsal lumbotomi. Insisi diperdalam sampai ke bagian rongga retroperitoneal. Ditemukan ginjal multikistik displastik dan dilakukan nefro-ureterektomi sedistal mungkin. Kemudian sampel yang diperoleh di kirim ke laboratorium patologi anatomi untuk pemeriksaan histopatologi dengan hasil yang diperoleh seperti pada Gambar 3.

Setelah operasi, penderita dirawat di ruang anak dan di terapi menggunakan antibiotik cefoperazone sulbactam $300 \mathrm{mg}$ per $12 \mathrm{jam}$, anti nyeri berupa fentanyl 0,7 ml/jam (fentanyl $100 \mathrm{mcg}$ diencerkan di dalam $20 \mathrm{ml} \mathrm{NaCl} \mathrm{0,9 \% )} \mathrm{dan} \mathrm{perawatan} \mathrm{luka}$ setiap dua hari sekali. Setelah empat hari menjalani perawatan, penderita mulai membaik dan tidak memiliki keluhan sehingga akhirnya di-pulangkan. Dua minggu setelah operasi, hasil pemeriksaan histopatologi menunjukkan gambaran ginjal multi-kistik displastik seperti yang ditampilkan pada Gambar 4.

\section{PEMBAHASAN}

Kelainan ureter ektopik merupakan suatu kelainan kongenital yang jarang terjadi. Insiden kelainan ini $1 / 2.000$ sampai $1 / 4.000$ kelahiran pada populasi secara umum dengan perbandingan jenis kelamin perempuan lebih banyak daripada laki-laki, yaitu 6:1 atau sekitar $70-90 \%$ pada perempuan. ${ }^{8}$ Sebagian besar kelainan ini didiagnosa pada masa kanakkanak. ${ }^{3,4}$ Patogenesis terjadinya ureter ektopik disebabkan karena terdapat defek pada hubungan antara uretero-trigonal. ${ }^{9}$ Selain itu, dapat juga terjadi karena mutasi genetic Ret, Fgfr2, dan Gata3. ${ }^{10-12}$ Umumnya, perempuan datang dengan keluhan inkontinensia urin dan berhubungan dengan duplikasi sistem pelvis-ureter. Pada kasus kami, penderita tidak memiliki keluhan inkontinensia, tetapi memiliki riwayat infeksi saluran kemih berulang. Hal ini disebabkan karena muara ureter ektopik terletak di uretra proksimal di atas dari sfingter uretra eksterna.

Kelainan kongenital lain seperti displasia ginjal dan anomali non-genitourinari (penyakit jantung bawaan, malformasi medula spinalis, malformasi ano-rektal, dll) dapat terjadi bersamaan dengan ureter ektopik. ${ }^{13}$ Pasien kami memiliki kelainan ureter ektopik bersamaan dengan ginjal multikistik displastik (MCDK). MCDK merupakan penyebab paling umum dari penyakit kistik ginjal pada periode perinatal. ${ }^{14}$ Kejadian MCDK berkisar dari 1/3.600 sampai 1/4.300 kelahiran hidup, dan sebagian besar didiagnosis pada pemeriksaan ultrasonografi prenatal. ${ }^{14}$ Kelainan ini ditandai beberapa kista yang saling terpisah dengan berbagai variasi ukuran dan tidak adanya parenkim ginjal normal yang dapat diidentifikasi. ${ }^{4}$

Kombinasi pemeriksaan penunjang sangat penting untuk mengevaluasi ureter ektopik, khususnya pemeriksaan imaging untuk menetapkan diagnosis. Pada anak-anak, pemeriksaan ultrasonografi merupakan tes diagnostik awal, tetapi terkadang dengan pemeriksaan ultrasonografi saja tidak cukup membantu. ${ }^{6}$ Umumnya pemeriksaan ultrasonografi dan VCUG digunakan sebagai tes lini pertama untuk diagnosis, tetapi studi lain menunjukkan adanya pilihan lain. Glylys-Morin VM et al., menggunakan MRI untuk mendeteksi ureter 
ektopik. ${ }^{15}$ MRI memiliki beberapa keuntungan, dimana MRI dapat digunakan pada pasien dengan fungsi ginjal yang sudah menurun, menggambarkan anatomi dengan jelas, dan tidak memiliki paparan radiasi. Tetapi tidak semua rumah sakit memiliki fasilitas MRI dan pemeriksaan MRI membutuhkan biaya yang lebih besar dibanding pemeriksaan lainnya.

Studi dari Hanson GR et al., menunjukkan CT scan dengan kontras dapat digunakan untuk mendiagnosis ureter ektopik. ${ }^{5}$ Metode ini dinilai lebih sensitif dan dapat memberikan gambaran anatomi yang jelas, termasuk letak muara ureter ektopik. ${ }^{5}$ Pada kasus kami, dari hasil ultrasonografi menunjukkan kistik multiple dengan penipisan pada korteks ginjal yang menggambarkan ginjal multikistik dipslastik. Selanjutnya kami melakukan pemeriksaan voiding cysto-uretrography dan didapatkan vesiko-ureteral refluks grade $\mathrm{V}$ dengan ureter ektopik. Untuk mengetahui letak muara ureter ektopik, kami melakukan pemeriksaan sistoskopi dengan retrograde pyelografi dan uretero-renoskopi.

Ureter ektopik dengan sistem pelvis-ureter tunggal seringkali memiliki fungsi ginjal yang buruk, sehingga pembedahan nefro-uretrektomi lebih sering dipilih, baik dengan pendekatan open ataupun dengan pendekatan laparoskopi. Ketika fungsi ginjal masih baik atau pada keadaan duplikasi sistem pelvis ureter dengan pool atas masih berfungsi dengan baik, teknik pembedahan yang dapat dipilih berupa reimplantasi ureter atau ureteroureterostomi. Menurut Lee YS maupun Churcill BM et al., kasus ureter ektopik sistem tunggal dengan ginjal displastik, direkomendasikan dilakukan nefrektomi dengan pendekatan laparoskopi. ${ }^{16,17}$ Pada kasus kami, kami memutuskan untuk melakukan nefroureterektomi, karena selain terdapat sistem tunggal ureter ektopik dengan ginjal displastik, pasien juga sering mengalami infeksi saluran kemih berulang akibat refluks dari buli-buli. Dikhawatirkan bila dilakukan reimplantasi ureter, akan terjadi refluks berulang yang dapat menyebabkan komplikasi yang lebih berat, seperti gagal ginjal.

\section{SIMPULAN}

Insiden ureter ektopik bersamaan dengan ginjal multikistik displastik jarang ditemukan. Penderita ureter ektopik dengan ginjal multikistik displastik baru dapat diketahui bila sudah memiliki keluhan. Kombinasi pemeriksaan diagnostik sangat penting untuk mengevaluasi dan menetapkan diagnosis pada kelainan ureter ektopik. Selain untuk menjadi acuan dalam menentukkan penatalaksanaan, hal ini juga baik guna mencari kemungkinan adanya kelainan kongenital lainnya. Komplikasi pada penyakit ini dapat menyebabkan gangguan fungsi ginjal. Meskipun jarang terjadi, ginjal multikistik displastik dapat berubah menjadi suatu maligna, seperti karsinoma sel ginjal, tumor wilms dan mesothelioma. Tatalaksana pada kasus ureter ektopik bervariasi dan berbeda-beda untuk setiap kasus. Pembedahan yang dilakukan juga dipilih berdasarkan klinis dan hasil yang terbaik bagi pasien.

\section{KONFLIK KEPENTINGAN}

Tidak terdapat konflik kepentingan dalam penulisan laporan kasus ini.

\section{PENDANAAN}

Seluruh penulis bertanggung jawab terhadap pendanaan studi kasus ini.

\section{KONTRIBUSI PENULIS}

Keseluruhan penulis memiliki kontribusi yang sama dalam laporan kasus ini baik dari tahap penemuan kasus, tindakan operasi yang dilakukan, maupun luaran klinis yang diperoleh dimana disampaikan pada publikasi ini

\section{DAFTAR PUSTAKA}

1. McLoughlin MA, Chew DJ. Diagnosis and surgical management of ectopic ureters. Clin Tech Small Anim Pract. 2000;15(1):17-24

2. Roy Choudhury S, Chadha R, Bagga D, Puri A, Debnath PR. Spectrum of ectopic ureters in children. Pediatr Surg Int. 2008;24(7):819-823.

3. Ghosh B, Shridhar K, Pal DK, Banerjee M. Ectopic ureter draining into the uterus. Urol Ann. 2016;8(1):105-107.

4. Cassart M, Majoub N, Irtan S, et al. Prenatal Evaluation and Postnatal Follow-Up of Ureteral Ectopic Insertion in Multicystic Dysplastic Kidneys. Fetal Diagn Ther. 2019;45(6):373-380.

5. Hanson GR, Gatti JM, Gittes GK, Murphy JP. Diagnosis of ectopic ureter as a cause of urinary incontinence. J Pediatr Urol. 2007;3(1):53-57.

6. Duicu C, Kiss E, Simu I, Aldea C. A Rare Case of DoubleSystem With Ectopic Ureteral Openings Into Vagina. Front Pediatr. 2018;6:176.

7. Joyeux L, Lacreuse I, Schneider A, et al. Long-term functional renal outcomes after retroperitoneoscopic upper pole heminephrectomy for duplex kidney in children: a multicenter cohort study. Surg Endosc. 2017;31(3):1241-1249.

8. Chen CY, Tsao TF, Chang HM, et al. Bladder agenesis and bilateral ectopic ureters draining into the vagina in a female infant: demonstrated by MR imaging. Surg Radiol Anat. 2012;34(1):89-92. doi:10.1007/s00276-011-0838-2

9. Demir M, Çiftçi H, Kılıçarslan N, et al. A case of an ectopic ureter with vaginal insertion diagnosed in adulthood. Turk J Urol. 2015;41(1):53-55.

10. Sims-Lucas S, Di Giovanni V, Schaefer C, Cusack B, Eswarakumar VP, Bates CM. Ureteric morphogenesis requires Fgfr 1 and Fgfr2/Frs2 $\alpha$ signaling in the metanephric mesenchyme. J Am Soc Nephrol. 2012;23(4):607-617. 
11. Reginensi A, Hoshi M, Boualia SK, Bouchard M, Jain S, McNeill H. Yap and Taz are required for Retdependent urinary tract morphogenesis. Development. 2015;142(15):2696-2703.

12. Chia I, Grote D, Marcotte M, Batourina E, Mendelsohn C, Bouchard M. Nephric duct insertion is a crucial step in urinary tract maturation that is regulated by a Gata3Raldh2-Ret molecular network in mice. Development. 2011;138(10):2089-2097.

13. Nazer II, Alhashmi G, Sharief SN, et al. A case of urinary bladder agenesis and bilateral ectopic ureters: a case report. BMC Urol. 2018;18(1):83.

14. Al Naimi A, Baumüller JE, Spahn S, Bahlmann F. Prenatal diagnosis of multicystic dysplastic kidney disease in the second trimester screening. Prenat Diagn. 2013;33(8):726-731.

15. Gylys-Morin VM, Minevich E, Tackett LD, Reichard E, Wacksman J, Sheldon CA. Magnetic resonance imaging of the dysplastic renal moiety and ectopic ureter. J Urol. 2000;164(6):2034-2039.
16. Lee YS, Im YJ, Kim SW, et al. The vagaries of proper imaging in diagnosing single-system ectopic ureter in children with continuous incontinence and outcomes of simple nephrectomy. J Pediatr Surg. 2016;51(3):469-474.

17. Churchill BM, Abara EO, McLorie GA. Ureteral duplication, ectopy and ureteroceles. Pediatr Clin North Am. 1987;34(5):1273-1289.

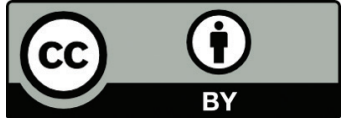

This work is licensed under a Creative Commons Attribution 